\title{
Particle size of beclomethasone dipropionate produced by two nebulisers and two spacing devices
}

\author{
Christopher O'Callaghan
}

\begin{abstract}
An impactor method was used to assess the amount of beclomethasone dipropionate in particles less than $5 \mu \mathrm{m}$ produced by two nebulisers (Pari Inhalierboy, Medix Traveller compressor with cirrhus nebuliser chamber) and two spacer devices (Volumatic and Nebuhaler). After nebulisation of $3 \mathrm{ml}$ (150 $\mu \mathrm{g})$ beclomethasone dipropionate the amount of drug in particles less than $5 \mu \mathrm{m}$ was $16 \mu \mathrm{g}$ (GSD 1.1) with the Pari Inhalierboy, and $27 \mu \mathrm{g}(1.4)$ with the Medix Traveller with cirrhus nebuliser. This was less than the amount in particles less than $5 \mu \mathrm{m}$ after three metered dose inhaler actuations $(150 \mu \mathrm{g})$ from the Nebuhaler (58.2 (1) $\mu \mathrm{g})$ or the Volumatic spacer $(46 \cdot 5(1) \mu \mathrm{g})$. The greater amount of beclomethasone dipropionate in small particles with administration from a metered dose inhaler with a spacer device means that considerably more drug is likely to reach the airways than when the same dose is given by the two nebulisers studied.
\end{abstract}

Beclomethasone dipropionate delivered by metered dose aerosol or powder capsule usually results in a substantial improvement in asthmatic children who have responded poorly to sodium cromoglycate. Trials using nebulised beclomethasone dipropionate have failed to show similar improvement. ${ }^{1-3}$

The aim of this study was to determine whether the apparent difference in response to beclomethasone given by nebuliser and by metered dose or dry powder inhaler can be attributed to differences in the amount of drug in particles small enough to reach the airways.

Department of Child Health, University Hospital, Nottingham C O'Callaghan

Address for reprint requests: Dr C O'Callaghan,

Department of Child Health, University Hospital, Nottingham NG7 2UH.

Accepted 1 November 1989

Three millilitres of beclomethasone dipropionate nebuliser solution $(50 \mu \mathrm{g} / \mathrm{ml})$ was cloud was sucked through the impinger at a flow rate of $60 \mathrm{l} / \mathrm{min}$. Nebulisation was continued until no further aerosol had been produced for one minute. This was repeated on seven occasions to increase the amount of beclomethasone dipropionate in each stage of the impinger. We assessed two nebuliser systems, the Pari Inhalierboy and the Medix Traveller compressor with a cirrhus nebuliser chamber. We measured the output from six different nebulisers of each system.

Two large volume spacing devices were also assessed, the $750 \mathrm{ml}$ Volumatic (Allen and Hanburys) and the Nebuhaler (Astra). Beclomethasone dipropionate aerosol $(50 \mu \mathrm{g} /$ actuation) was fired into the spacer with the valve closed. The mouthpiece of the spacer device was then placed into the mouthpiece of the multistage liquid impinger. The contents of the spacer was sucked through the impinger. This was repeated on 25 occasions for each spacing device tested. Six different Nebuhaler and Volumatic spacer devices were studied.

\section{ANALYTICAL DETERMINATION}

Impinger samples containing beclomethasone dipropionate were collected in methanol/water $(50 / 50)$ and assayed against a range of known concentration beclomethasone dipropionate standards prepared in methanol/water $(50 / 50)$ from beclomethasone dipropionate powder $\left(98.5^{\circ}{ }_{0} \mathrm{w} / \mathrm{w}\right)$. The results were calculated on a mean peak height basis, standard mean response factors being used.

\section{TEST SOLUTION}

On the basis of the data acquired for the multistage liquid impinger, together with a $50 \%$ cutoff diameter for each stage of the device, a plot of aerodynamic diameter against cumulative percentage of particles below each size was constructed. This graph was used to calculate the mass median aerodynamic diameter (MMAD - the droplet diameter at which half the aerosol mass is contained in smaller droplets and half in larger droplets) and its geometric standard deviation (GSD-the ratio of $84.1 \%$ diameter to the MMAD $50 \%$ diameter). The GSD is a measure of the width of the distribution of droplet diameter. The percentage of aerosol mass contained in droplets less than $5 \mu \mathrm{m}$ was also calculated.

\section{STATISTICAL ANALYSIS}

Results were compared by the Wilcoxon unpaired rank sum test. placed in the nebuliser chamber. The nebuliser

\section{Results}

The MMAD (GSD) was $2.4 \mu \mathrm{m}$ (3) and $8 \mu \mathrm{m}$ (1.5) for the Medix Traveller and Pari Inhalier- 


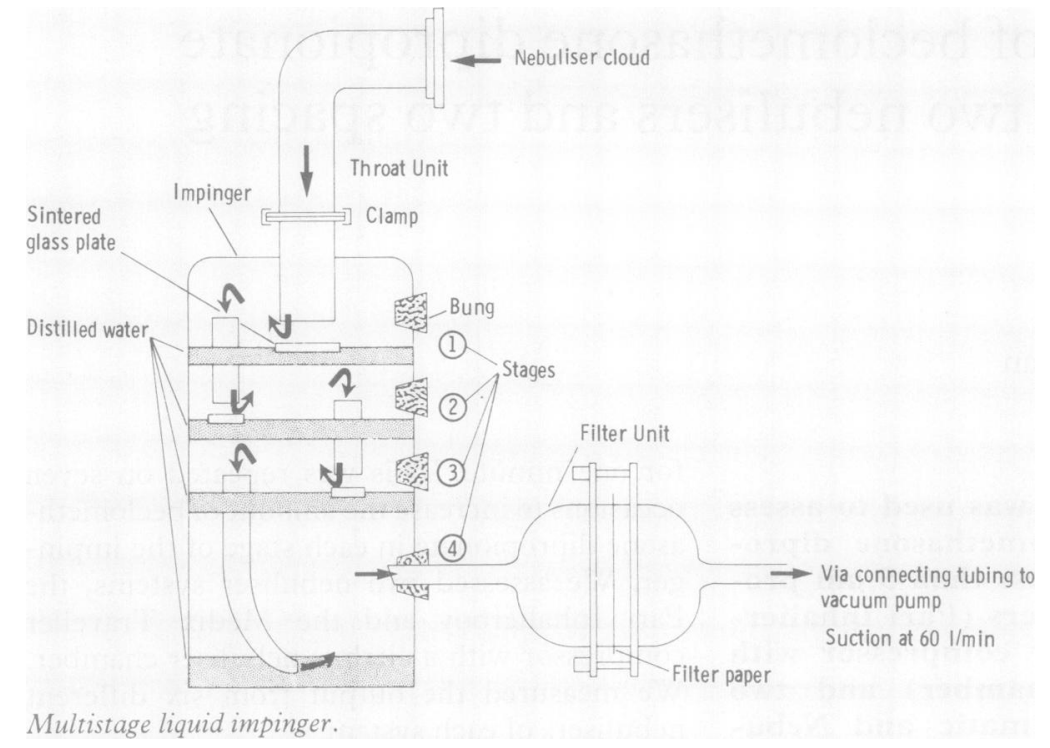

boy and $3.3(1.75)$ and $3.5(1.8) \mu \mathrm{m}$ for the Volumatic and Nebuhaler devices. The Medix Traveller produced a greater amount of drug contained in particles less than $5 \mu \mathrm{m}(27(1.4)$ $\mu \mathrm{g})$ than the Pari Inhalierboy $(16(1 \cdot 1) \mu \mathrm{g})$ ( $\mathrm{p}<0.001$; table).

With the Nebuhaler a greater amount of drug was contained in particles less than $5 \mu \mathrm{m}$ $(58.2(1) \mu \mathrm{g})$ than with the Volumatic spacing device $(46.5$ (1) $\mu \mathrm{g} ; \mathrm{p}<0.01)$.

The amount of beclomethasone dipropionate in particles less than $5 \mu \mathrm{g}$ recovered from the Nebuhaler or Volumatic spacing devices per $150 \mu \mathrm{g}$ dose was significantly greater than that recovered from either of the nebulisers studied $(\mathrm{p}<0.01)$ (table).

The time taken to nebulise $3 \mathrm{ml}$ beclomethasone dipropionate was 15 minutes with the Pari Inhalierboy and 20 minutes with the Medix Traveller and cirrhus nebuliser chamber combination.

\section{Discussion}

Beclomethasone dipropionate when given by nebuliser does not appear to be as effective as when given as a dry powder or from a metered dose inhaler in children. ${ }^{1-3} \mathrm{Webb}$ et al used the Pari Inhalierboy to deliver beclomethasone dipropionate to young children, with little success. ${ }^{1}$ Using the same nebuliser and the same amount of beclomethasone dipropionate ( $3 \mathrm{ml}: 150 \mu \mathrm{g}$ ), we found that the nebulised aerosol cloud contained $57 \cdot 7 \mu \mathrm{g}$ of the original $150 \mu \mathrm{g}$ beclomethasone dipropionate. Only 16 $\mu \mathrm{g}$, however, was in particles less than $5 \mu \mathrm{m}$. The inspired dose is likely to be considerably smaller as the inspiratory time is about a third of the respiratory cycle. On this assumption the amount of beclomethasone dipropionate in particles less than $5 \mu \mathrm{m}$ available for inhalation would be about $5 \mu \mathrm{g}$ per dose. The nebulisation time for the Pari Inhalierboy was lengthy (average 15 minutes) owing to the viscosity of the suspension.

More beclomethasone dipropionate was contained in particles less than $5 \mu \mathrm{m}$ with the Medix Traveller them with the Pari Inhalierboy even though the total drug output was greater with the latter. The Pari Inhalierboy produces larger particles than the Medix Traveller, as has been found with sodium cromoglycate. ${ }^{6}$ The low total output of drug from the Medix Traveller may be due to a more efficient baffle system that returns larger particles to the suspension. This probably explains in part why the Medix traveller took several minutes longer to nebulise to dryness than the Pari Inhalierboy. The residual volume of drug in the nebuliser chamber was not measured.

Warner and Reizer ${ }^{3}$ described substantial improvement in asthmatic children not responding to sodium cromoglycate when given beclomethasone dipropionate via a Nebuhaler. Only one child given nebulised beclomethasone dipropionate showed improvement. Two studies of nebulised beclomethasone dipropionate in infants ${ }^{78}$ suggest that topical corticosteroids when given for an extended period may have a beneficial effect.

Aerosol size is the most important factor determining the site of aerosol deposition within the respiratory tract. ${ }^{9}$ For the same initial dose of beclomethasone dipropionate a much greater amount of drug was contained in particles of less than $5 \mu \mathrm{m}$, and hence likely to reach the lungs, when the drug was given by the spacing devices than with the nebuliser (table). This finding is the likely explanation for the poorer response of asthmatic children to nebulised beclomethasone dipropionate than to beclomethasone dipropionate given by metered dose inhaler. Because of the lengthy time needed for nebulisation larger nebulised doses are impracticable.

A Nebuhaler spacer device has been modified by adding a Laerdal resuscitation facemask to the inspiratory port. Ipratropium bromide given in this way produced bronchodilatation in wheezing infants. ${ }^{10}$ This device may enable adequate amounts of beclomethasone dipropionate or budesonide in a suitable particle size range and dose to be given to children of any age.

I would like to acknowledge Mr Paul Wood-

Total amount of aerosol recovered per dose and amount of beclomethasone dipropionate (BDP) in particles less than 5 um per dose

\begin{tabular}{|c|c|c|c|c|}
\hline & $\underset{(\mu m)}{M M A D}$ & $G S D$ & $\begin{array}{l}\text { Total BDP ( } \mu g) \\
\text { from } 150 \mu g \text { dose }\end{array}$ & $\begin{array}{l}\text { Amount of } B D P(\mu g) \text { in } \\
\text { particles }<5 \mu m\end{array}$ \\
\hline $\begin{array}{l}\text { Volumatic } \\
\text { Nebuhaler } \\
\text { Pari Inhalierboy } \\
\text { Medix Traveller }{ }^{\dagger}\end{array}$ & $\begin{array}{l}3 \cdot 3 \\
3 \cdot 5 \\
8 \\
2 \cdot 42\end{array}$ & $\begin{array}{l}1.75 \\
1.8 \\
1.5 \\
2.5\end{array}$ & $\begin{array}{l}63(1 \cdot 7) \\
85 \cdot 8(3) \\
57 \cdot 7(2) \\
36 \cdot 4(1 \cdot 8)\end{array}$ & $\begin{array}{l}46 \cdot 5(1) \\
58 \cdot 2(1) \\
16(1 \cdot 1) \\
27(1 \cdot 4)\end{array}$ \\
\hline
\end{tabular}

$\star 3 \times 50 \mu$ g actuations (SD).

MMAD - mass median aerodynamic diameter; GSD—geometric standard deviation. 
cock of Bath University for preparing the assays of beclomethasone dipropionate and the Mason Medical Trust for financial support with this project.

1 Webb MSC, Milner AD, Hiller EJ, Henry RL. Nebulised beclomethasone dipropionate suspension. Arch Dis Child 1986;61:1108-10.

2 Storr J, Lenney CA, Lenney W. Nebulised beclomethasone dipropionate in pre-school asthma. Arch Dis Child 1986;61:270-3.

3 Warner J, Reiser J. Inhaled glucocorticosteroids in childhood asthma. In: Godfrey S, ed. Glucocorticosteroids in childhood asthma. Amsterdam: Excepta Medica, 1987: 78-86.
4 May KC. Multistage liquid impinger. Bac Rev 1966;30: $559-70$

5 Bell JH, Brown K, Glasby J. Variation in delivery of isoprenaline from various pressurised inhalers. $J$ Pharm Pharmacol 1973;2S(suppl):32-6.

6 O'Callaghan C, Clark AR, Milner AD. Why nebulise for more than five minutes? Arch Dis Child 1989;64:1270-3.

7 Carlsen KH, Leegood J, Larson S, Orston KI. Nebulised beclomethasone dipropionate in recurrent obstructive episodes acute bronchiolitis. Arch Dis Child 1988;63:1428-33.

8 Maayan C, Itzhaki T, Bar-Vistray E, Cross S, Tal A, Godfrey $S$. The functional response of infants with persistent wheezing to nebulised beclomethasone dipropionate. Paediatr Pulminol 1986;2:9-14.

9 Agnew JE. Physical properties and mechanisms of deposition of aerosols. In: Clarke SW, Pavia D, eds. Aerosols and the lungs. London: Butterworths, 1984:49-70.

10 O'Callaghan C, Milner AD, Swarbrick A. Spacer device with facemask attachment as a drug delivery system for young asthmatics. Br Med J 1989;298:160-7. 